duty to ensure that people whose jobs come to an end or whose prospects are unreasonably dimmed must be given some kind of help to find other outlets for their energies. No doubt there will be some talk of compensation payments. No doubt attempts will be made to fit people in elsewhere within government establishments. But it would be better in the long run, and a good precedent as well, if the Government were to recognize that what the circumstances require is a thorough-going programme of retraining and resettlement backed up by generous schemes for helping people move from place to place. One of the ironies of the two decades since the war is the growth of the assumption that scientists working in some narrow field cannot be expected to transfer their interests to some other. It seems to have been forgotten that during the Second World War every other biologist was trained to be a radar engineer almost overnight. If the country is really short of talent, and if the Ministry of Technology is anxious somehow to increase the effectiveness of what there is, it should put its energies into making full use of the people who will no longer be fully occupied at Culham.

\section{SPEAKING FOR UNIVERSITIES}

THERE is something entirely appropriate about the election of the new chairman of the Committee of ViceChancellors and, in the same week, the announcement that the Department of Education and Science will, after all, assume direct responsibility for seeing that universities spend public money in a manner which is seemly but as yet undefined (see page 576). The universities have never been as much in need of somebody who can act on behalf of them all. With one thing and another it has been a bad year for the universities. For one thing, it is becoming ominously to seem that the first bite at the Robbins cherry may also be the last. Gone already is the heady talk of how the university system might grow and grow so as to provide a substantial part of the adult education on which such hopes as may survive for British economic prosperity must rest. The gloom which has been accentuated by the tactless handling of the equipment grants by the University Grants Committee may lift when the funds for the five years from 1968 are announced later in the year, but nobody can be cheerful at this stage. And then there is the galling incident of the Government's decision to increase fees for university students from overseas without properly consulting the universities. Yet the universities themselves have done very little to face up to the problems which confront them. Such talk as there may have been of more efficient operation seems to have been largely ineffectual. The Standing Conference on University Entrance will probably come out with more liberal rules for admission in the next few months, but the universities as a whole have done little more than Oxford after Franks to protect themselves from criticism.

This is why the new chairman of the Committee of Vice-Chancellors can play a decisive role. It has been plain for the past five years that the UGC is less and less effective as a buffer between the universities and the Government. That this should have happened is inevitable. The growth of the scale on which the universities are supported by public funds is less important than the now open abandonment of the whole convention that universities should be protected from the knowledge that they are living on taxpayers' money. Indeed, it is no longer possible for a government to allow that universities acting for themselves should make important decisions affecting public policy. And it is, of course, entirely sensible that the Government should have the last word about questions such as the proportion of the British GNP to be consumed by higher education. A good many in the universities will agree with that. Yet the universities must be able to retain freedom over academic policy and self-respect as well. Even if the UGC can keep for itself something more than the role of being Sir Herbert Andrew's auditing department, there is now no chance that a body of civil servants like the UGC can set itself up as a means of keeping an effective dialogue with the Government on university policy and, when necessary, as over fees for overseas students, to defy the Government. For a long time it has been obvious that only the Committee of Vice-Chancellors could fill that role.

But what needs to be done? The most immediate task which Dr Christopherson should undertake is to let it be known that the Committee of Vice-Chancellors is not some kind of quasi-judicial body, a pillar of the establishment, but an institution which must be reckoned a political force. For too long the committee has sought to win respect by making itself almost inaudible on matters of public policy. The trouble, of course, is that if it is to carry university opinion, the committee must function publicly, making statements, publishing newsletters and sometimes even taking steps to improve its standing with the nonacademic world. If on some occasion it finds that the Government has not consulted it on important issues of principle, it should feel free and strong enough to take unilateral action on its own account. (A public appeal for funds to make up overseas fees would have been an interesting exercise.) And then, of course, the committee must somehow capture the respect and the loyalty of the separate universities, so that it can act quickly on their collective behalf. This in turn will imply that universities must delegate some of their freedom of aetion to the committee and, lower down the hierarchy, that university departments must give up some of their present autonomy for the greater good. How far things can go in these directions, only time will tell. But clearly one of the most obvious needs is that the chairman of the committee should command respect. Fortunately, Dr Christopherson is the sort of man who will appreciate what needs to be done. 